\title{
Med biblioteket som allieret i e-læringsmiljøer
}

\author{
Karen Harbo \\ Udviklingskonsulent \\ Biblioteket ved Aarhus School of Business \\ har@asb.dk \\ http://www.asb.dk/lib
}

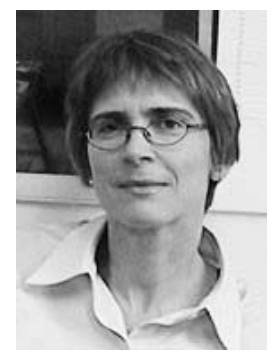

\section{Helle Stenholt}

Fuldmægtig AC

Biblioteket ved Aarhus School of Business

hes@asb.dk

http://www.asb.dk/lib

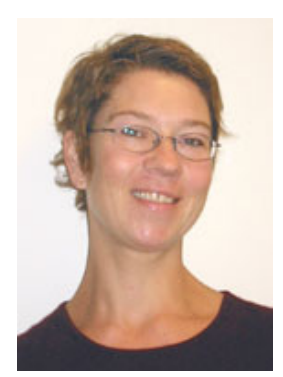

Karen Harbo er bibliotekar og Master i IT, Sprog og Lcring. Hun fungerer som kontaktperson til ISEK med særligt henblik på undervisningsgrupperne fransk og kommunikation, samt forskergrupperne Virksomhedskommunikation , Videnskommunikation og Center for Medicinsk Fagsprog. Karen Harbo er ansvarlig for ASB bibliotekets udviklingsområde for samarbejdet mellem biblioteket og læring.

Helle Stenholt er cand.ling.merc. i spansk og kontaktperson til ISEK med scrligt fokus på undervisningsgrupperne spansk og engelsk samt forskergrupperne overscttelse og tolkning, sprogsystem og sprogbrug og Center for Leksikografi. Helle har i kraft af kontaktpersonfunktionen beskceftiget sig meget med oprettelse og vedligeholdelse af en fagportal for forskergruppen for overscttelse og tolkning, samt oprettelse af e-kompendier.

\section{Indledning}

Biblioteket ved Aarhus School of Business (ASB) har organiseret sit virke ud mod de uddannelsesfaglige miljøer. Hvert af de seks institutter ved ASB, Institut for Ledelse, Institut for Marketing og Statistik, Institut for Regnskab, Finansiering og Statistik, Juridisk institut, Nationaløkonomisk institut og Institut for Sprog og Erhvervskommunikation, kan trække på et antal biblioteksmedarbejdere, som er særligt dedikerede i forhold til netop dét specifikke faglige miljø. Således stiller biblioteket tre personer til rådighed for Institut for Sprog og Erhvervskommunikation (ISEK), hver af disse med særlige forudsætninger for at kunne sætte sig ind i de faglige emnefelter for de undervisnings- og forskningsgrupper, som findes på ISEK. Undervisningsgrupperne retter sig mod fagområderne, engelsk, tysk, fransk, spansk, europæiske studier og kommunikation. Forskningsgrupperne retter sig mod fagområderne virksomhedskommunikation, leksikografi, virksomhedens ikke-økonomiske omgivelser, sprogsystem og sprogbrug, oversættelse og tolkning og videnskommunikation. Biblioteksmedarbejderne samarbejder, og er i løbende dialog med det videnskabelige personale ved ISEK om

- materialeanskaffelser til bibliotekets samlinger, det være sig trykt eller elektronisk materiale,

- introduktion og undervisning i fleksible adgange til de mange elektroniske ressourcer, der gives adgang til gennem biblioteket, 
- formidling af metoder til søgning og håndtering af information i læreprocessen; personlig knowledge management,

- Registrering af forskning ved ASB: Research@asb,

- formidling af viden om ophavretsmæssige problemer i forbindelse med elektronisk publicering af litteratur,

- etablering af fagportaler til specifikke undervisnings- og forskningsområder,

- etablering af elektroniske e-kompendier i forbindelse med den virtuelle læringsplatform ved ASB, CampusNet.

\section{E-læring}

Både biblioteker og uddannelser har i de senere år bevæget sig frem mod mere og mere virtuelt baseret kommunikation, formidling og undervisning.

Bibliotekerne er blevet hybride forstået på den måde, at de som institutioner håndterer tilgang til både trykt og elektronisk materiale - og formidlingen om dette foregår både face-to-face i biblioteket og gennem bibliotekernes virtuelle hjemmesider på nettet. Bibliotekerne arbejder både i og med det fysiske og det virtuelle læringsrum.

Uddannelserne har på samme måde bevæget sig i retning mod en virtuel understøttelse af læring - ofte anvendes blended learning, som både rummer elementer af møder i det fysiske rum og møder i det virtuelle rum. Faktuel viden om det pågældende uddannelsesforløb samles i læringsplatforme på nettet, som giver mulighed for også at supplere med dialog og kommunikation mellem studerende og undervisere. Således findes på ASB, som ovenfor nævnt, den virtuelle læringsplatform CampusNet. CampusNet rummer information om samtlige kursusfag ved ASB, og i denne kontekst trækkes ressourcer fra ASB biblioteket ofte ind fx i form af e-kompendier til den pågældende kursusvirksomhed eller i form af gennemstilling til en for kurset relevant fagportal.

\section{Elektroniske ressourcer}

De mange elektroniske informationsressourcer, som ASB biblioteket køber licensadgang til, skal være målrettet til forskning og undervisning ved samtlige uddannelser på ASB. Disse licensadgange supplerer de åbne og frit tilgængelige ressourcer på internettet og er for de studerende, undervisere og forskere ved ASB lige så umiddelbart tilgængelige. For ISEK's vedkommende gælder det, at især kommunikationsstudierne kan understøttes med mange relevante elektroniske informationsressourcer, men også for sprog- og områdestudiernes vedkommende findes efterhånden adgang til mange anvendelige ressourcer, fx aviser og nyhedstjenester; ressourcer som kan inddrages direkte i virtuelle læringsforløb og -platforme, da mange licenser er indgået på kontrakter, som tillader, at ressourcerne frit kan anvendes i uddannelsessammenhænge. Ofte er det dog sådan, at den litteratur, som anvendes i sprog- og områdestudierne, hidrører fra bøger frem for tidsskrifter. Der findes imidlertid også flere og flere elektroniske bøger på markedet. Bøger som ASB biblioteket på samme måde som med de elektroniske tidsskrifter køber licensadgang til. For sprog- og områdestudierne kan det konstateres, at der er stigende interesse for og sammenfald mellem udbud og efterspørgsel på de elektroniske titler, som ASB biblioteket stiller til rådighed.

Vi har valgt at lade nedenstående to cases give et billede af, hvordan ASB biblioteket samarbejder med uddannelserne på ISEK i forhold til læring på nettet.

1. E-kompendier

2. Fagportaler 


\section{Case 1: Samarbejde om etableringen af et e-kompendie til et undervisningsforløb}

\subsection{En forespørgsel}

En underviser fra undervisningsgruppen fransk henvender sig til biblioteket, og spørger om det vil være en ide at oprette et e-kompendium til et kursusforløb for sine sprogstuderende på bachelorniveau. Kurset er oprettet på CampusNet, og her henter de studerende al øvrig information om kurset. Den pågældende underviser har førhen benyttet fortrykte kompendier, som de studerende har købt. E-kompendierne skal de studerende selv printe ud fra nettet. Det kan de gøre i den takt, de måtte ønske det.

Underviseren synes umiddelbart godt om tanken om, at litteraturen til kurset kan præsenteres via CampusNet, og hun tænker også lidt på, om det vil kunne lade sig gøre i løbet af kurset at føje nye tekster til. Det vil give nogen fleksibilitet. Desuden mener hun, at biblioteket har købt licensadgang til nogle af de tidsskrifter, som hun bruger artikler fra. Måske kan det lade sig gøre at linke direkte ind til disse artikler og derved gennemstille de studerende til onlineudgaven af artiklen. Det ville være fint og en god måde at få de studerende gjort opmærksom på denne adgang, som biblioteket og ASB betaler adgang til. Det kan indimellem være svært for de studerende at finde ind til de mange elektroniske ressourcer, og dette vil være en god og faglig relevant måde at gøre de studerende opmærksom på denne mulighed for at finde kilder til information.

Det er underviserens erfaring, at de studerende kan synes, at de farer vild i de mange forskellige veje, der findes til informationskilder. At anvise vejen i en faglig kontekst vil, synes hun, give god mening for de studerende.

\subsection{Dialog og muligheder}

I en samtale med den kontaktperson på biblioteket, som er knyttet til undervisningsgruppen for fransk, får underviseren at vide, at i de tilfælde hvor artiklen findes i et af de elektroniske tidsskrifter, som biblioteket abonnerer på, vil de studerende blive ledt målrettet til den relevante artikel. I enkelte tilfælde vil det dog ikke være muligt at linke helt ind til en artikel, men dog så langt at de studerende vil have data nok i referencen til selv at kunne finde helt ind til den pågældende artikel.

Dette forhold har at gøre med de respektive licenskontraktaftaler og endvidere, at det ikke er lovligt at dyblinke i hjemmesider, som ligger frit tilgængeligt på internettet, medmindre der foreligger en særlig aftale. Underviseren mener dog nok, at de studerende vil kunne finde vej, og hun taler med bibliotekaren om, at det kan styrke de studerendes evne til selv at skulle navigere det sidste stykke vej frem mod den ønskede tekst. I begge de førnævnte tilfælde vil de studerende blive gjort opmærksom på en sammenhæng, som vil kunne komme dem til nytte i nye situationer, hvor de får brug for selv at søge information. De studerende får altså både præcis den artikel, de har brug for, samt bliver gjort opmærksom på en litterær kontekst, som er relevant i den konkrete studiesammenhæng.

Ikke al den ønskede litteratur findes dog i elektronisk form på biblioteket, og en del af den litteratur som underviseren vil anvende på kurset, er også uddrag af bøger. Underviseren får imidlertid at vide, at biblioteket har indgået en aftale med Copydan, som giver lov til at indskanne dele af trykte bøger og tidsskrifter og derefter give adgang til de indskannede elektroniske versioner indenfor rammer af et e-kompendie. Det gør således ingen forskel, i forhold til at få oprettet et e-kompendium, om de kilder til information, underviseren ønsker at bygge sin undervisning på, er trykte eller elektroniske. Dog er der regler, som sætter grænser 
for, hvor stort omfanget af det trykte materiale må være, for at det kan indskannes, og i et par tilfælde må underviseren skære i teksterne, for at kunne holde sig inden for disse regler. Men underviseren synes, at det går an, og hun er vant til, også i forbindelse med de trykte kompendier, at skulle tage hensyn til omfanget af sine kursustekster. Det viser sig dog, at et enkelt af de kapitler, som underviseren ønsker at bruge i sin kursussammenhæng, findes i en e-bog, som biblioteket har købt licensadgang til, og i det tilfælde kan der stilles direkte om til det pågældende kapitel på nettet.

\subsection{Realisering}

Enkelte af de tekster, som underviseren henviser til, findes frit tilgængeligt på internettet. I nogle af disse tilfælde findes den relevante tekst i et dybere lag af den pågældende hjemmeside, og biblioteket kan, som tidligere nævnt på baggrund af ophavsretsloven, ikke dyblinke til disse. Her må de studerende igen selv navigere det sidste stykke frem til den relevante tekst. Sidegevinsten er, at opmærksomheden skærpes i forhold til den faglige kontekst for den valgte kilde, samt at den selvstændige navigation øger evnen til at søge i kilder til information.

Efter at have diskuteret disse muligheder igennem med biblioteket beslutter underviseren sig for at få biblioteket til at oprette et e-kompendium i forbindelse med sit kursusforløb. Biblioteket garanterer, at e-kompendiet kan være klart i løbet af 14 dage, og da underviseren har været i god tid med sin forespørgsel, bliver det ikke noget problem at få e-kompendiet klart til kursusstart.

Efter 14 dage modtager underviseren en internetadresse til e-kompendiet samt adgangskoder, som de studerende skal oplyses om skal behandles fortroligt. I toppen af hvert e-kompendium linkes endvidere til oplysning om de ophavsretslige forhold, som de studerende skal være bekendt med, når de bruger e-kompendiet. Underviseren checker sit e-kompendium igennem for at se om alting er, som det skal være. Det er det, og hun sender nu information om adgang til e-kompendiet med de tekster, som de studerende skal læse i løbet af kurset.

\subsection{Præsentation og reaktion}

Det er første gang, netop disse studerende får adgang til et e-kompendium, og de skal lige vænne sig til, at det ikke længere er et færdigtrykt materiale, som de kan købe sig til. De studerende skal selv printe teksterne ud - og for egen regning. Til gengæld kan de gøre det hvor, og hvornår de vil. Teksterne kan altid nås over CampusNet. Nogle af teksterne kan det, afhængigt at printerkapacitet og indskanningens karakter, tage lidt tid at printe ud. Det er alt sammen forhold, som der skal tages højde for i udskrivningssituationen, men underviseren oplyser om dette, og de studerende indstiller sig i langt de fleste tilfælde på, at det er sådan. De har brug for at diskutere den nye situation, men de mærker, at underviseren tror på den, og de kan godt se fordelene og fleksibiliteten.

Underviseren oplever også fleksibiliteten, både i løbet af semesteret og i det næste. Hun beder en enkelt gang under kursusforløbet om at få føjet en ny tekst til sit kompendium, og i næste semester kan hun se, at hun kan genbruge flere af teksterne i et andet kursusforløb. Hun vender derfor tilbage til biblioteket og beder om at få oprettet endnu et e-kompendium, dels på baggrund af nogle af sine gamle tekster, dels på baggrund af en række nye, som hun føjer til. Desuden har hun talt med en anden underviser om en tekst, som vedkommende har brugt i en kursussammenhæng, hvor biblioteket ligeledes har oprettet et e-kompendium. Denne tekst genbruger hun også. 
Le Francais des affaires: L'entreprise

HA-int.-studiet fransk 4. semester, forår 2006

Aase Møller

Minimum requirements for access

Litteratur

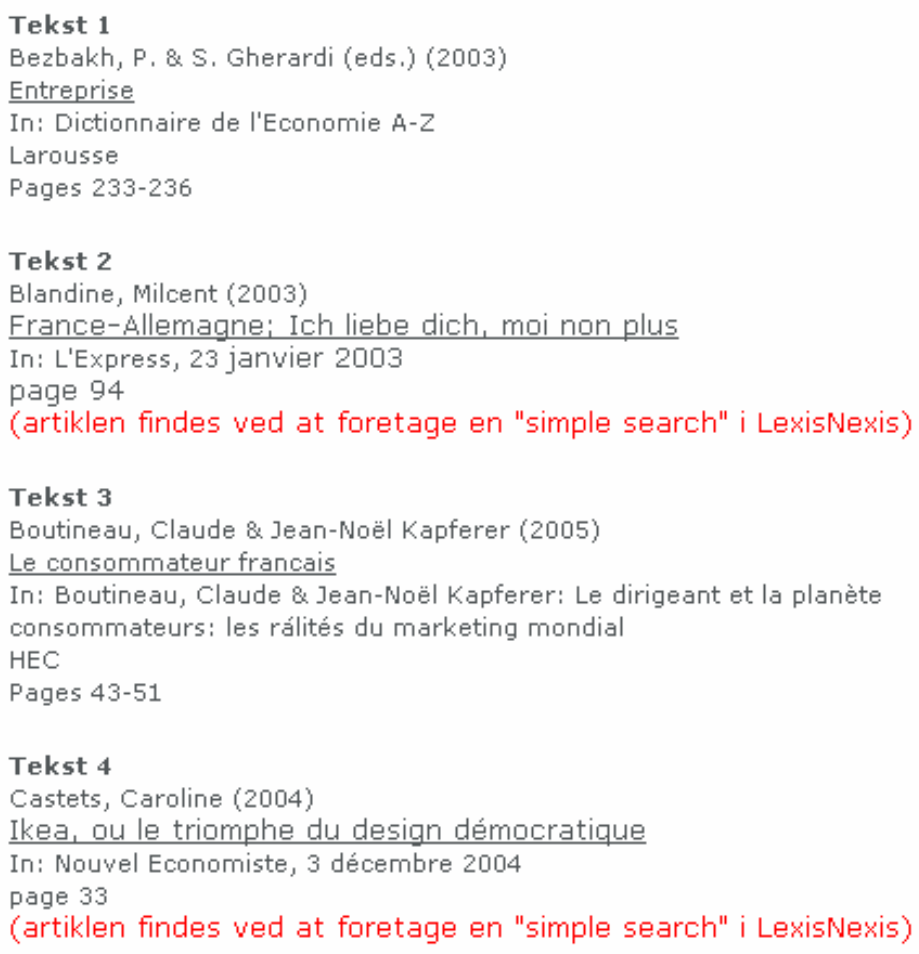

Fig. 1: Ovenstående giver en illustration af et e-kompendie etableret i foråret 2006

\section{Case 2: Samarbejde om etablering af en fagportal til en forskergruppe}

Da Forskergruppen for oversættelse og tolkning for nogle år siden blev dannet som det daværende Fakultetscenter for Tolkning henvendte kontaktpersonen for forskergruppen sig til ASB biblioteket for at høre, om ikke der kunne oprettes en fagportal til forskergruppen. Fagportalen blev dannet ud fra tanken om, at bestemte målgrupper skulle have en let tilgængelig samlet adgang til Bibliotekets informationsressourcer inden for emnet oversættelse og tolkning. En adgang, der kunne fås via Internettet, uanset hvor man befandt sig.

Bibliotekets kontaktperson udvalgte i samarbejde med forskergruppens kontaktperson en række links og søgestrenge, som blev samlet inden for emnerne oversættelse og tolkning. Dette lagde grunden til fagportal for Forskergruppen for oversættelse og tolkning, som henvender sig til en bestemt målgruppe, nemlig cand.ling.merc.-studerende på tolke- og translatør-linien, forskere inden for tolkning og oversættelse samt andre undervisere og 
interesserede. Som en særlig målgruppe kan nævnes studerende ved masteruddannelsen

European Master of Translation. Gruppen er spredt såvel nationalt som internationalt og kan derfra, hvor de er, bruge portalen, da den kan tilgås via internettet, og da informationsressourcerne, der er stillet til rådighed via denne fagportal, kan nås via fjernadgang.

Portalens links og søgestrenge blev efter input fra forskergruppens kontaktperson emneordnet i en hensigtsmæssig faglig struktur: tolkning- og oversættelsesrelevante databaser og tidsskrifter, anbefalet litteratur osv. (se illustration længere nede i artiklen). Disse links viser for det meste hen til bibliotekets informationsressourcer, men også til frit tilgængelige onlineressourcer. Det er en måde, hvorpå vejen til bibliotekets informationsressourcer gøres lettere tilgængelig for de studerende. Kilder til information præsenteres her i en faglig kontekst.

Biblioteket foreslog, at fagportalen blev oprettet i et program, hvor en opdeling af skærmbilledet gør, at der i venstre side ligger et statisk billede med emneopdelte links. Højre side af billedet viser selve linkets indhold og er således dynamisk.

Linkene viser dels mod online-ressourcer som fx tidsskrifter og databaser, hvor der via biblioteket er fuldtekstadgang, dels mod sider, som indeholder referencer på publikationer vedrørende emnet. Disse henvisninger linker ind i bibliotekets katalog, hvorfra materialet kan rekvireres.

Samarbejdet foregår løbende i en tæt kontakt mellem bibliotekets kontaktperson og forskergruppens kontaktperson, der på vegne af forskergruppen kommer med input til indholdet af fagportalen - det være sig nye bøger eller tidsskrifter, som biblioteket skal anskaffe, inden for emnerne oversættelse og tolkning.

Punkterne "Relevant litteratur” og "Anbefalet litteratur” (se illustration længere nede i artiklen) skal især fremhæves, da disse er stærkt emneopdelt. Strukturen og emneopdelingen i fagportalen vurderes løbende i samarbejde mellem bibliotekets kontaktperson og forskergruppens kontaktperson, da brugsværdien afhænger af en god og struktureret præsentation af fagportalens indhold.

”Relevant litteratur” indeholder links til søgninger i Merkur på bl.a. afhandlinger om tolkning, afhandlinger om oversættelse og på ph.d. afhandlinger om de to emner.

"Anbefalet litteratur" er naturligvis stærkt præget af forskergruppens erfaringer med litteraturen inden for emnet. Litteraturen er her opdelt emnemæssigt, og der er også her oprettet dokumenter med henvisninger til publikationerne og som nævnt ovenfor refereres der også her via hyperlinks direkte ind i bibliotekskatalogen.

Efter at fagportalen har eksisteret i en årrække, er den nu under omformning. Det er aftalt mellem bibliotekets kontaktperson og forskergruppens kontaktperson, at rammerne for fagportalen skal ændres, for at den kan passe ind i ASB's nye web. Fagportalen vil i sin nye form snarest blive gjort tilgængelig via ASB’s content management system.

De ydre rammer ændrer sig altså, men indholdet er lige relevant og udvikles til stadighed. Forskergruppen ønsker fx flere links til søgninger i bibliotekets katalog på forskellige relevante og mere specifikke emneord. Strukturen udvikler sig således fortsat, men fokus er stadig på oversættelse og tolkning.

Denne fagportal er et eksempel på, hvordan ASB biblioteket i et samarbejde mellem på den ene side repræsentanter fra et forskningsområde og på den anden side bibliotekets kontaktperson kan bidrage til e-læringsmiljøet. Den er et eksempel på, hvordan man kan 
skræddersy og målrette specifikke ressourcer til en specifik målgruppe via et tæt samarbejde mellem uddannelse og bibliotek, og på, hvordan bibliotekets online-ressourcer og ressourcer i det hele taget bedre kan udnyttes og gøres synlige i en e-læringssammenhæng.

Herunder den statiske opdeling af den nuværende fagportal for Forskergruppen for oversættelse og tolkning:

\section{Databaser}

Fuldtekstdatabaser på Biblioteket

MLA

The AIIC Bibliography

Translation Studies Bibliography

\section{Nyhedsliste}

Anskaffelser 2004 på Biblioteket

Bestillinger på Biblioteket

Tidsskrifter

Babel

The CIRIN Bulletin

HERMES - tidsskrift for sprogforskning

The Interpreters' Newsletter

Interpreting

META

Multilingua

Parallèles - ophørt

Perspectives: Studies in Translatology

Target

Translator

Relevante publikationer

Søgning i bibliotekets database på emnet Tolkning

Afhandlinger om tolkning

Ph.d. afhandlinger

Afhandlinger om oversattelse

Anbefalet litteratur

Forskningsmetode

Oversattelsesteori

Tolkeforskning

Tolkning i praksis

\section{Forskning ved $\mathrm{HH} \AA$}

Handelshøjskolens forskningsdatabase

Forskning - Fakultetscenter for Tolkning

Relevante internetlinks

European Society for Translation Studies

Biblioteket

Herunder strukturen for den kommende fagportal:

\section{Databaser:}

- AIIC Bibliography

- MLA

- Translation Studies Bibliography 


\section{Nyheder:}

- Nyanskaffelser

- Bestillinger

\section{Tidsskrifter:}

- Babel

- CIRIN Bulleting

- Hermes

- The Interpreters' Newsletter

- Interpreting. International Journal of research and practice in interpreting

- International Journal of Localisation

- International Journal of Speech, Language and the Law

- META

- Multilingua

- Perspectives: Studies in Translatology

- Target

- The Translator

\section{Anbefalet litteratur}

- Forskningsmetodik

- Forskning i oversættelse og tolkning

- Lærebøger og vejledninger om professionel oversættelse og tolkning

- Søgning i Merkur under emneord

o Forskningsmetodik

o Oversættelse

o Synkronisering

o Tekstning

o Tolkning

- Afhandlinger om oversættelse og tolkning på ISEK
o Specialeafhandlinger
o PhD-afhandlinger

- Forskergruppens publikationer (trækkes fra Research@asb)

Link til forskergruppens hjemmeside hvorfra der er link til fagportalen:

http://www.asb.dk/about/departments/isek/forskning/forskergrupper/tolkning.aspx

\subsection{At være bibliotek i et e-læringsmiljø}

De to cases er konkrete eksempler på to af de i indledningen nævnte områder, hvor biblioteksmedarbejdere samarbejder og er i løbende dialog med det videnskabelige personale, undervisere og forskere ved ISEK

- etablering af fagportaler til specifikke undervisningsområder

- etablering af elektroniske e-kompendier i forbindelse med den virtuelle læringsplatform ved ASB, Campusnet 
Det forholder sig dog sådan, at de forskellige områder har med hinanden at gøre, og derved trækkes det ene ofte ind, når det andet berøres. De øvrige områder optræder alle indirekte i begge cases

- materialeanskaffelser til bibliotekets samlinger, det være sig trykt eller elektronisk materiale

- introduktion og undervisning i fleksible adgange til de mange elektroniske ressourcer, der gives adgang til gennem biblioteket

- Registrering af forskning ved ASB: Research@asb

- formidling af metoder til søgning og håndtering af information i læreprocessen; personligt knowledge management

- formidling af viden om ophavsretsmæssige problemer i forbindelse med elektronisk publicering af litteratur

Materialeanskaffelser indgår både i samarbejdet om etablering og udvikling af fagportalen til forskergruppen for oversættelse og tolkning og i arbejdet med e-kompendierne. I begge cases spiller den fleksible adgang til bibliotekets elektroniske ressourcer en central rolle, og det samme gør sig gældende for metoder til søgning og håndtering af information i læreprocessen. Online-registrering af forskning ved ASB kan være særdeles relevant at inddrage i en fagportal for en forskergruppe, og grundtanken bag både e-kompendiet og fagportalen er i høj grad at gøre med at koble kilder til information til den faglige formidling. Endelig er viden om ophavsretsmæssige problemer netop en del af kompleksiteten bag ekompendierne, fx ved at de alene stilles til rådighed gennem adgangskontrol.

For at agere på det ene område må de andre af de ovennævnte områder sættes i spil. At være bibliotek i et e-læringsmiljø kræver således et beredskab på flere fronter. Et beredskab, som kan følge, arbejde og samarbejde med uddannelserne ind i det virtuelle niveau. Det betyder, at biblioteket fortsat skal satse på udvikling, og biblioteket ved ASB forsøger fortsat at være både aktiv og proaktiv i forhold til at indgå i samarbejder med uddannelserne om e-læring. 